\title{
Penurunan Depresi pada Difabel Akibat Kecelakaan melalui Pelatihan Keterampilan Regulasi Emosi
}

\author{
Rini Setyowati, Nisa Rachmah Nur Anganthi, Setia Asyanti ${ }^{1}$ \\ Magister Psikologi Profesi Universitas Muhammadiyah Surakarta
}

\begin{abstract}
This study examined the effect of emotion regulation skills training in reducing depression on disability due to an accident. Researchers use nonrandomized design pretest-posttest control group by subjekts as many as 12 early adult disability due to an accident which is divided into an experimental group and a control group. Beck Depression Inventory (BDI) was used to measure the level of depression before, after treatment and follow-up. Based on the results of quantitative analysis with statistical test nonparametric Mann-Whitney $U$, it is known there are differences in decreased depression in the experimental group were given training in comparison with the control group, and Wilcoxon T, it is known there are significant differences between the scores of depression before and after training the experimental group. Qualitative data also support quantitative analysis, that emotion regulation skills in the subjects of the experiment increased after training. It was concluded that emotion regulation skills training proved effective in reducing depression in disabilities due to accidents. Therefore, it is necessary container for the disabled as a result of the accident to share and express emotions
\end{abstract}

Keywords: accidental disability, adult earlier, depression, emotion regulation skills training

\begin{abstract}
Abstrak. Penelitian ini bertujuan untuk menguji pengaruh pelatihan keterampilan regulasi emosi dalam menurunkan depresi pada difabel akibat kecelakaan. Peneliti menggunakan desain nonrandomized control group pretest-posttest dengan subjek sebanyak 12 difabel dewasa awal akibat kecelakaan yang terbagi menjadi kelompok eksperimen dan kelompok kontrol. Beck Depression Inventory (BDI) digunakan untuk mengukur tingkat depresi sebelum, setelah perlakuan dan tindak lanjut. Berdasarkan hasil analisis kuantitatif dengan uji statistik non parametrik Mann-Whitney $U$, diketahui terdapat perbedaan penurunan depresi pada kelompok eksperimen yang diberi pelatihan dibandingkan dengan kelompok kontrol, dan Wilcoxon $T$, diketahui terdapat perbedaan yang signifikan antara skor depresi sebelum dan setelah pelatihan pada kelompok eksperimen. Data kualitatif juga mendukung analisis kuantitatif, bahwa keterampilan regulasi emosi pada subjek eksperimen meningkat setelah mengikuti pelatihan. Disimpulkan bahwa pelatihan keterampilan regulasi emosi terbukti efektif dalam menurunkan depresi pada difabel akibat kecelakaan. Oleh karena itu, diperlukan wadah bagi difabel akibat kecelakaan untuk saling berbagi dan mengekspresikan emosi.

Kata Kunci: depresi, dewasa awal, difabel akibat kecelakaan, pelatihan keterampilan regulasi emosi
\end{abstract}

\footnotetext{
${ }^{1}$ Korespondensi mengenai isi artikel ini dapat dilakukan melalui: rini.setyowati87@gmail.com, anganthi@gmail.com, setia_asyanti@yahoo.com
} 
Angka kecelakaan semakin memprihatinkan setiap tahunnya. Kecelakaan lalu lintas di seluruh dunia menewaskan hampir 1,2 juta jiwa dan menyebabkan cedera sekitar enam juta orang setiap tahunnya (Kemenhub RI, 2011). Data BPS yang bersumber dari Kepolisian Republik Indonesia, kecelakaan lalu lintas di Indonesia mulai tahun 2008 sampai 2012 berjumlah 415.257 kasus (BPS, 2014). Kecelakaan merupakan kejadian yang tidak diinginkan, tidak diduga dan mengakibatkan kerugian materi dan berdampak pada kesehatan. Dampak kesehatan dari kecelakaan tersebut meliputi kesehatan fisik dan psikologis. Dampak fisik dari kecelakaan dapat berupa kecacatan tubuh yang dialami oleh korban. Individu yang mengalami hal tersebut biasanya dikenal dengan sebutan difabel.

Difabel akibat kecelakaan seringkali menghadapi stigma negatif dari lingkungan sekitar yang merujuk pada praktik diskriminasi (ableism) yang cenderung merendahkan dan membatasi potensi penyandang disabilitas. Praktik ini merentang mulai dari pemberian komentar dan label negatif, pelecehan, isolasi sosial, sampai pada penetapan kebijakan atau prosedur organisasi yang bersifat mengucilkan (Yusainy, Thohari \& Gustomy, 2016). Perlakuan yang demikian juga akan memberi kontribusi terhadap dampak psikologis yang dialami difabel akibat kecelakaan.

Kecacatan atau difabel yang dialami setelah kecelakaan akan memengaruhi pertumbuhan, perkembangan perilaku, dan emosi sehari-hari (Senra, 2011). Perubahan drastis seperti kecelakaan yang mengakibatkan kecacatan, terutama pada fisiknya, memberi tekanan psikologis yang sangat besar bagi individu yang mengalaminya. Menurut Senra (2011), dampak psikologis yang mengikuti difabel antara lain: (1) depresi; (2) trauma; (3) marah; (4) shock; (5) tidak dapat menerima keadaan; dan (6) bunuh diri adalah dampak ekstrim dari dampak psikologis setelah mengalami kecelakaan.

Balai Besar Rehabilitasi Bina Daksa (BBRSBD) merupakan tempat rujukan nasional yang setiap tahun menerima siswa difabel dari berbagai daerah di Indonesia. Berdasarkan hasil dokumentasi laporan Praktek Kerja Profesi Psikologi (PKPP) yang dilakukan beberapa praktikan di BBRSBD Prof. Dr. Soeharso Surakarta pada tahun 2014, banyak ditemukan kasus depresi pada penyandang difabel akibat kecelakaan. Penyandang difabel tersebut merasa cemas, sedih, malu, kurang percaya diri, tertekan, dan tidak berharga dengan kondisi cacat setelah kecelakaan yang dialaminya. Siswa tersebut sering diam, menyendiri, menyalahkan diri sendiri atas kejadian yang menimpa dirinya, merasa tidak memiliki kepastian dalam kehidupan dan beranggapan masa depannya suram, bahkan ada seorang siswa yang melakukan percobaan bunuh diri. Siswa tersebut memiliki ketidakstabilan emosi sehingga mudah marah, berteriak-teriak, menarik diri dari lingkungan sosial, dan cenderung menghindar dalam menghadapi permasalahan (Candra, 2014). Kondisi ini menunjukkan bahwa siswa difabel mengalami gejala depresi dan memiliki reaksi emosi yang negatif.

Depresi menurut Beck (1985), merupakan suatu "primary mood disorder" atau sebagai suatu "affective disorder". Beck memandang depresi dalam komponenkomponen sebagai berikut: (1) Depresi merupakan kesedihan yang berkepanjangan dan keadaan jiwa yang apatis (komponen afektif); (2) Depresi merupakan cara berpikir yang salah dalam 
memandang realitas di luar dan di dalam diri sendiri, sehingga terbentuk konsep diri yang negatif yang berlanjut pada perasaan rendah diri (komponen kognitif); (3) Depresi merupakan gangguan terhadap fungsi fisiologis yang antara lain menyebabkan sukar tidur dan hilangnya nafsu makan serta seksual (komponen fisiologis); (4) Depresi merupakan hilangnya kemampuan untuk berfungsinya secara wajar serta hilangnya dorongan dan energi untuk bertindak (komponen perilaku).

Penanganan terhadap depresi dapat berupa penanganan biologis, psikologis, intervensi sosio kultural dan interpersonal seperti yang dikemukakan oleh Halgin dan Whitbourne (2010). Menurut Compare, Zarbo, Shonin, Gordon dan Marconi (2014) pendekatan intervensi untuk depresi dengan mengembangkan regulasi emosi yang efektif dapat berupa terapi berbasis kesadaran, terapi fokus emosi, dan terapi regulasi emosi. Pengembangan regulasi emosi diperlukan karena strategi regulasi emosi yang disfungsional berpengaruh dalam patogenesis depresi dan penyakit fisiologis, sedangkan strategi regulasi emosi adaptif menyebabkan pengurangan emosi stres yang menimbulkan gangguan fisik. Penelitian mengenai depresi dan regulasi emosi juga dilakukan oleh Joorman dan Gotlib (2010) yang menemukan bahwa depresi dipengaruhi oleh penggunaan regulasi emosi yang digunakan. Perbedaan individu dalam menggunakan strategi regulasi emosi, memainkan peran penting dalam pemulihan dari depresi dan dapat meningkatkan risiko untuk kambuh.

Pelatihan keterampilan regulasi emosi dalam penelitian ini merupakan kegiatan yang dilakukan dengan memberi pengertian, pengetahuan, dan kecakapan untuk memonitor, mengevaluasi, dan memodi- fikasi reaksi emosional serta bagaimana emosi tersebut diekspresikan, sehingga peserta dapat mengaplikasikan untuk meningkatkan kemampuan regulasi emosi yang dimiliki. Selain itu, dalam pelatihan ini juga menggunakan konsep keterampilan regulasi emosi dari Greenberg (2002) berupa kemampuan individu dalam mengelola emosi-emosi negatif maladaptif menjadi emosi yang positif dan adaptif.

Adapun keterampilan yang akan dilatih dalam pelatihan ini antara lain: (1) Keterampilan memonitor emosi adalah keterampilan yang diberikan untuk meningkatkan kemampuan individu dalam menyadari dan memahami keseluruhan proses yang terjadi di dalam diri, seperti: perasaan, pikiran, dan latar belakang dari tindakan (Gross, 2006). Kesadaran diri akan membantu tercapainya aspek-aspek yang lain. Memonitor emosi membantu individu terhubung dengan emosi-emosi, pikiran-pikiran, dan keterhubungan ini membuat individu mampu mengenal dan menamakan setiap emosi yang muncul. Individu yang memiliki kemampuan mengenal emosi yang baik, akan dapat memberikan reaksi emosi yang baik dan tepat dan pada akhirnya dapat terhindar dari keadaan distres psikologis (Hidayati, 2008); (2) Keterampilan mengevaluasi emosi yaitu keterampilan yang diberikan untuk meningkatkan kemampuan individu dalam mengelola dan menyeimbangkan emosi-emosi yang dialami (Gross, 2006). Kemampuan mengelola emosi khususnya emosi negatif seperti kemarahan, kesedihan, dan benci akan membuat individu terbawa dan terpengaruh secara mendalam, sehingga individu tidak mampu lagi berpikir rasional. Pengaturan emosi dapat dilakukan dengan cara latihan dan relaksasi. Gross dan Thompson (2007) menyatakan bahwa latihan dan relaksasi 
merupakan cara untuk dapat mengatur emosi negatif dan dapat digunakan untuk mengurangi perilaku psikologis yang mengganggu misalnya sifat agresif atau depresif. Individu yang mampu mengatur emosi negatifnya akan lebih mudah untuk mengendalikan emosi dan menemukan cara yang tepat untuk menyikapi emosi tersebut, sehingga memunculkan perilaku yang tepat pula; (3) Keterampilan mengekspresikan emosi adalah keterampilan yang diberikan untuk meningkatkan kemampuan individu dalam mengungkapkan perasaan atau emosinya, baik positif ataupun negatif kepada orang lain (Greenberg, 2002). Kemampuan mengekspresikan emosi baik secara lisan maupun tulisan dapat membantu meningkatkan kesehatan, kesejahteraan psikologis dan fungsi fisik pada seseorang saat menghadapi peristiwa traumatik dalam hidupnya, juga dapat meningkatkan proses penyembuhan dan kesehatan mental, membantu mengatasi distress psikologis, mengurangi emosi-emosi negatif dan menurunkan simptom-simptom depresi (Greenberg, 2002). Keterampilan mengekspresikan emosi dalam pelatihan ini ditekankan pada pentingnya membagi perasaan (katarsis) kepada orang lain dan mencari penyelesaian permasalahan sehingga beban-beban psikologis yang dirasakan dapat berkurang; (4) Keterampilan memodifikasi emosi yaitu keterampilan yang diberikan untuk meningkatkan kemampuan individu dalam mengubah emosi sedemikian rupa sehingga mampu memotivasi diri terutama ketika individu berada dalam keadaan putus asa, cemas, dan marah (Gross, 2006). Modifikasi emosi ini dapat berupa mengubah emosi negatif menjadi emosi positif. Emosi positif baik berupa optimisme, kebahagiaan, perilaku memaafkan, harapan, cinta maupun rasa syukur, terbukti dapat mengatasi dan mengurangi kecenderungan stres dan depresi, meningkatkan kemampuan relisiensi, serta mereduksi munculnya penyakit dan mempercepat proses penyembuhan akibat peristiwa yang menekan (Hidayati, 2008). Individu yang memiliki emosi positif lebih dapat bersikap adaptif terhadap berbagai stressor kehidupan. Kemampuan ini membuat individu mampu menumbuhkan optimisme dalam hidup sehingga mampu bertahan dalam masalah yang membebani, mampu terus berjuang ketika menghadapi hambatan yang besar, dan tidak mudah putus asa serta kehilangan harapan.

Hipotesis yang diajukan dalam penelitian ini adalah : (1) Ada perbedaan penurunan depresi pada kelompok eksperimen yang telah diberi pelatihan keterampilan regulasi emosi dibandingkan dengan kelompok kontrol; (2) Ada penurunan depresi yang signifikan pada kelompok eksperimen antara sebelum dan sesudah diberi pelatihan keterampilan regulasi emosi.

\section{Metode}

Penelitian ini merupakan penelitian eksperimen kuasi dengan menggunakan model non randomized control group pretestpost test design. Variabel yang menjadi fokus dalam penelitian ini meliputi variabel tergantung yaitu depresi dan variabel bebas yaitu pelatihan keterampilan regulasi emosi.

Subjek dalam penelitian ini berjumlah 12 orang yang memiliki kriteria inklusi sebagai berikut: (1) difabel akibat kecelakaan; (2) berusia 20-29 tahun dan dikategorikan sebagai dewasa awal; (3) pendidikan dari tingkat SD hingga SMA; (4) tingkat depresi sedang atau berat berdasarkan Beck Depression Inventory (BDI); dan (5) mengisi lembar informed consent pelatihan keterampilan regulasi 
emosi. Pengambilan subjek penelitian dengan tingkat depresi sedang atau berat ini dimaksudkan agar bersifat homogen dan memastikan bahwa subjek penelitian pada kelompok eksperimen dan kontrol berada dalam kondisi yang sama pada saat baseline dan sebelum eksperimen (pretest). Subjek penelitian tersebut dibagi menjadi dua kelompok, yaitu kelompok eksperimen yang mendapat perlakuan berupa pelatihan keterampilan regulasi emosi dan kelompok kontrol tidak diberikan perlakuan tetapi akan diberikan pelatihan keterampilan regulasi emosi setelah penelitian selesai (waiting list).

Metode pengumpulan data dalam penelitian ini adalah dengan menggunakan Beck Depression Inventory dari Aaron T. Beck yang telah diadaptasikan oleh Saleh Achmad (1988) dan diperbanyak oleh Laboratorium Fakultas Psikologi Universitas Muhammadiyah Surakarta. Beck (1985) melakukan seleksi terhadap simtom depresi, kemudian menyusun menjadi 21 kategori simtom yang disusun dari A sampai U yang dapat dikelompokkan menjadi empat kelompok simtom, yaitu: (1) Kelompok simtom afektif pada huruf item ADJK (kesedihan, ketidakpuasan, frekuensi menangis, dan kejengkelan atau lekas marah); (2) Kelompok simtom motivasional pada huruf item BILMO (pesimis, keinginan atau ide bunuh diri, kecenderungan menarik diri dari hubungan sosial, ketidakmampuan mengambil keputusan, dan kelambanan dalam bekerja); (3) Kelompok simtom kognitif pada huruf item CEFGHN (perasaan gagal, perasaan bersalah, pengharapan akan dihukum, rasa tidak suka terhadap diri sendiri, menyalahkan diri sendiri, dan perubahan kesan pada tubuh); (4) Kelompok simtom fisik dan vegetatif pada huruf item PQRSTU, yaitu gangguan tidur, mudah lelah, hilangnya nafsu makan, perubahan berat badan, tanggapan yang salah mengenai tubuh, dan hilangnya libido.

Menurut Beck (1985), kategorisasi dari nilai BDI dapat dilihat pada tabel 1 . Metode pengumpulan data tambahan yang digunakan dalam penelitian ini adalah wawancara sebelum dan setelah perlakuan, observasi, tugas rumah, worksheet serta lembar evaluasi yang diisi oleh subjek selama proses pelatihan. Lembar evaluasi digunakan untuk mengetahui sejauh mana pelatihan keterampilan regulasi emosi bermanfaat dalam mengelola emosi negatif.

Adapun pelaksanaan penelitian yaitu: (1) Memberikan baseline dengan Beck Depression Inventory (BDI) pada kelompok subjek. Kemudian subjek digolongkan menurut tingkat depresi berdasarkan skor yang diperoleh; (2) Mengelompokkan subjek yang memiliki tingkat depresi sedang atau berat menjadi kelompok kontrol dan eksperimen; (3) Memberikan pretest pada tanggal 23 Maret 2015 dengan

Tabel 1

Kategorisasi Total Nilai BDI

\begin{tabular}{lll}
\hline Klasifikasi & Nilai BDI & Tingkat Depresi \\
\hline \multirow{2}{*}{ Ringan } & $1-10$ & Normal \\
& $11-16$ & Gangguan depresi ringan \\
\multirow{2}{*}{ Sedang } & $17-20$ & Depresi sudah mengarah ke klinis \\
& $21-30$ & Depresi sedang \\
Berat & $31-40$ & Depresi berat \\
& Di atas 40 & Depresi ekstrim \\
\hline
\end{tabular}


Beck Depression Inventory (BDI) pada kelompok eksperimen dan kontrol; (4) Memberikan perlakuan berupa pelatihan keterampilan regulasi emosi pada kelompok eksperimen pada tanggal 23, 25 dan 28 Maret 2015, sedangkan kelompok kontrol tidak diberikan perlakuan (waiting list). Pelatihan ini menggunakan pendekatan experiential learning yang diberikan sebanyak 3 kali pertemuan yaitu 150-180 menit untuk tiap pertemuannya. Pelatihan pada pertemuan pertama terdiri dari sesi pembukaan, kondisi difabel, dan keterampilan memonitor emosi. Pelatihan pada pertemuan kedua terdiri dari sesi keterampilan mengevaluasi emosi, berlatih relaksasi dan keterampilan mengekspresikan emosi, sedangkan pertemuan ketiga terdiri dari sesi keterampilan memodifikasi emosi dan penutupan. Pelatihan diberikan oleh fasilitator dan dibantu co-fasilitator di BBRSBD Prof. Dr. Soeharso Surakarta. Modul pelatihan berupa modul fasilitator dan modul peserta yang berisi materi dan worksheet; (5) Memberikan postest dengan Beck Depression Inventory (BDI) pada kedua kelompok baik kontrol maupun eksperimen setelah diberi perlakuan; (6) Melakukan pengukuran kembali satu minggu dan dua minggu setelah pelatihan berlangsung sebagai tindak lanjut 1 dan tindak lanjut 2; (7) Menganalisis hasil perlakuan untuk mengetahui pengaruh perlakuan dan nonperlakuan pada depresi pada difabel akibat kecelakaan.

Analisis terhadap data yang diperoleh dalam penelitian ini diolah dengan statistik non-parametrik. Hal ini dikarenakan sampel yang digunakan dalam penelitian ini berjumlah sedikit. Analisis kuantitatif diperoleh dari skor Beck Depression Inventory (BDI) dengan menggunakan Mann-Whitney $U$ Test untuk melihat adanya perbedaan penurunan depresi pada kelompok eksperimen yang telah diberi pelatihan keterampilan regulasi emosi dibandingkan dengan kelompok kontrol (hipotesis I) dan Wilcoxon T Test untuk melihat apakah penurunan depresi pada kelompok eksperimen signifikan (hipotesis II).

Metode tambahan yang digunakan untuk memperkuat uji hipotesis adalah analisis kualitatif. Analisis kualitatif dilakukan dengan mencermati perubahan skor item dalam Beck Depression Inventory (BDI) pada pretest, posttest, tindak lanjut, wawancara pra dan pasca perlakuan, sharing, observasi, tugas rumah, data demografi, worksheet serta lembar evaluasi yang diisi oleh subjek selama proses pelatihan. Lembar evaluasi digunakan untuk mengetahui sejauh mana pelatihan keterampilan regulasi emosi bermanfaat dalam mengelola emosi negatif.

\section{H a s i 1}

\section{Hasil analisis kuantitatif}

Data yang diperoleh dalam penelitian ini adalah skor depresi antara kelompok eksperimen dan kontrol berdasarkan BDI yang diukur pada baseline, sebelum eksperimen (pretest), setelah eksperimen (posttest), setelah 1 minggu pelaksanaan pelatihan(tindak lanjut 1), dan setelah 2 minggu pelaksanaan pelatihan (tindak lanjut 2). Hasil rata-rata skor BDI pada kelompok eksperimen yaitu pada pengukuran baseline : 25,5, pretest : 26,333, postest : 12,167, tindak lanjut 1 : 9,667, dan tindak lanjut 2 : 10,667, sedangkan pada kelompok kontrol pada pengukuran baseline : 24,167 , pretest : 22,833 , posttest : 23,667, tindak lanjut 1 : 23,5, dan tindak lanjut $2: 22,5$.

Subjek penelitian baik pada kelompok eksperimen maupun kontrol berada dalam 
kondisi yang sama pada saat baseline dan sebelum eksperimen (pretest). Namun demikian, terjadi perbedaan skor depresi antara kelompok eksperimen dan kontrol setelah diberi perlakuan berupa pelatihan keterampilan regulasi emosi yang dapat dilihat pada gambar 1.

Grafik tersebut menunjukkan bahwa subjek penelitian baik pada kelompok eksperimen maupun kontrol berada dalam kondisi yang sama pada saat baseline dan sebelum eksperimen (pretest). Selanjutnya, terjadi penurunan skor depresi pada kelompok eksperimen dibandingkan kelompok kontrol pada pengukuran setelah pelatihan (postest), setelah 1 minggu (tindak lanjut 1), dan setelah 2 minggu pelaksanaan pelatihan (tindak lanjut 2).

Hasil penelitian menunjukkan bahwa hipotesis I yaitu ada perbedaan penurunan depresi pada kelompok eksperimen yang telah diberi perlakuan berupa pelatihan keterampilan regulasi emosi dibandingkan dengan kelompok kontrol dapat diterima. Hasil perhitungan uji hipotesis I pada kelompok eksperimen dan kelompok kontrol dapat dilihat pada tabel 2:
Tabel 2

Hasil Uji Hipotesis I

\begin{tabular}{lr}
\hline & Gainscore \\
\hline Mann-Whitney U & 0.000 \\
Wilcoxon W & 21.000 \\
Z & -2.892 \\
Asymp. Sig. (2-tailed) & 0.004 \\
Exact Sig. [2*(1-tailed Sig.)] & 0.002 \\
\hline
\end{tabular}

Tabel 2 menunjukkan bahwa besarnya nilai $\mathrm{z}$ hitung $-2,892$ dan nilai probabilitas (p) 0,002 < 0,05, maka dapat disimpulkan bahwa ada perbedaan penurunan depresi pada kelompok eksperimen yang telah diberi pelatihan keterampilan regulasi emosi dibandingkan dengan kelompok kontrol.

Selanjutnya hasil pengujian hipotesis II pada kelompok eksperimen dapat dilihat pada tabel 3.

Berdasarkan tabel 3, diketahui bahwa probabilitas ( $\mathrm{p}$ ) signifikansi pada baselinepretest $>0,05$, maka dapat disimpulkan bahwa tidak terdapat penurunan depresi yang signifikan pada kelompok eksperimen antara pada saat pengambilan data awal (baseline) dan sebelum pelaksanaan pelatihan keterampilan regulasi emosi

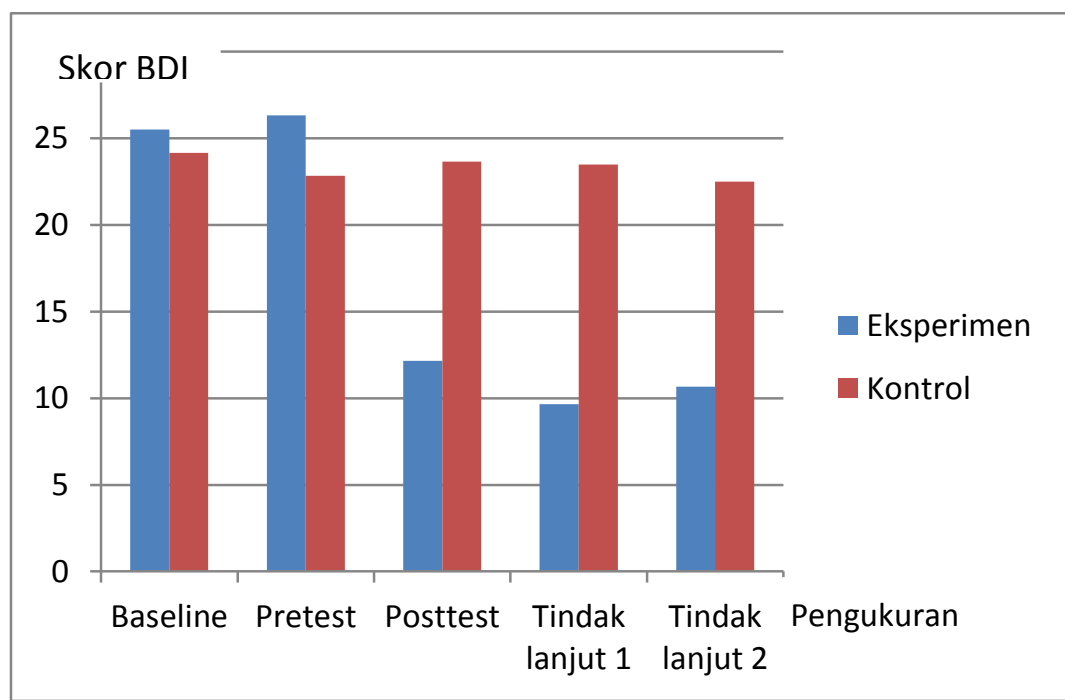

Gambar 1. Grafik Rata-rata Skor Depresi Kelompok Eksperimen dan Kontrol 
Tabel 3

Hasil Uji Hipotesis II

\begin{tabular}{lcccc}
\hline & Baseline-Pretest & Pretest-Posttest & $\begin{array}{c}\text { Posttest-Tindak } \\
\text { lanjut1 }\end{array}$ & $\begin{array}{c}\text { Tindak lanjut1- } \\
\text { Tindak lanjut2 }\end{array}$ \\
\hline Z & -0.962 & -2.207 & -2.041 & -0.707 \\
Asymp. Sig. (2-tailed) & 0.336 & 0.027 & 0.041 & 0.480 \\
\hline
\end{tabular}

(pretest). Sementara, probabilitas (p) signifikansi pada pretest-posttest (hipotesis I) dan posttest-tindak lanjut $1<0,05$, maka dapat disimpulkan bahwa terdapat penurunan depresi yang signifikan pada kelompok eksperimen antara sebelum (pretest) dan sesudah (posttest) serta antara sesudah (posttest) diberi perlakuan berupa pelatihan keterampilan regulasi emosi dan setelah 1 minggu pelaksanaan pelatihan (tindak lanjut 1). Penurunan depresi pada kelompok eksperimen ini tidak terjadi lagi pada saat antara setelah 1 minggu (tindak lanjut) dan setelah 2 minggu (tindak lanjut 1) pelaksanaan pelatihan keterampilan regulasi emosi. Hal ini diketahui dari nilai probabilitas (p) signifikansi tindak lanjut 1-tindak lanjut $2>0,05$.

\section{Hasil Analisis Kualitatif}

Subjek kelompok eksperimen dalam penelitian ini mengalami penurunan skor depresi yang telah diukur sebelum (pretest) dan setelah (posttest) pelatihan keterampilan regulasi emosi. Penurunan skor depresi tersebut juga cenderung stabil pada saat setelah 1 minggu (tindak lanjut 1) dan setelah 2 minggu pelaksanaan pelatihan (tindak lanjut 2). Penurunan skor depresi tersebut ditunjukkan dari skor Beck Depression Inventory (BDI) yang diisi oleh subjek. Dapat disimpulkan bahwa setelah mengikuti pelatihan, subjek tidak lagi mengalami kesulitan dalam menghadapi pengalaman emosi akibat perubahan kondisi fisik.
Penurunan depresi subjek disebabkan oleh meningkatnya keterampilan regulasi emosi yang dimiliki subjek setelah mengikuti pelatihan. Peningkatan tersebut tampak selama subjek mengikuti proses pelatihan, baik selama maupun setelah proses pelatihan berakhir. Peningkatan tersebut didukung oleh sikap kooperatif subjek dalam mengikuti seluruh proses pelatihan, sikap terbuka dalam sharing dan menceritakan pengalaman emosi mengenai kecelakaan yang dialaminya.

Ketika subjek melakukan relaksasi pernafasan diafragma, subjek merasakan perubahan, yaitu subjek merasa nyaman, rileks, dan tenang. Selama ini subjek mengalami ketegangan fisik ketika mengalami emosi negatif seperti marah, menyesal, dan bersalah. Setelah memperoleh keterampilan relaksasi pernafasan diafragma, subjek dapat mengelola ketegangan fisik yang dirasakan dan merasa lebih tenang. Subjek dapat mengurangi kelelahan fisik dan sulit tidur yang dialami selama ini dengan mempraktekkan relaksasi pernafasan diafragma.

Setelah pelatihan selesai, subjek mampu memahami situasi yang dialami terkait dengan perubahan kondisi fisik. Subjek dapat mengenali dan memahami perasaan dan emosi yang dimilikinya. Subjek menerima emosi dan perasaan yang dialami dalam menghadapi perubahan kondisi fisik. Subjek menyadari bahwa emosi tersebut wajar dialami oleh difabel akibat kecelakaan dan tidak lagi mengingkari perasaan dan emosi tersebut. 
Subjek mampu mengelola dan mengubah emosi tersebut menjadi emosi yang positif dengan memotivasi dan berpikiran positif terhadap suatu situasi.

Secara keseluruhan setelah mengikuti proses pelatihan, subjek merasakan adanya perubahan dalam diri yaitu menjadi lebih sabar dalam menghadapi pengalaman emosi, terutama emosi negatif. Perubahan tersebut membuat subjek mengalami penurunan depresi, antara lain simtom afektif, motivasional, kognitif, fisik dan vegetatif menjadi kecil.

\section{Diskusi}

Berdasarkan hasil uji hipotesis menunjukkan hipotesis yang menyatakan ada perbedaan penurunan depresi pada kelompok eksperimen yang telah diberi pelatihan keterampilan regulasi emosi dibandingkan dengan kelompok kontrol dapat diterima.

Penurunan skor depresi pada kelompok eksperimen terjadi secara signifikan. Artinya, pada kelompok eksperimen yang diberi pelatihan keterampilan regulasi emosi, terjadi penurunan skor depresi yang signifikan antara sebelum dan setelah pelatihan yang diberikan. Selain itu, penurunan skor depresi pada setelah satu minggu dan dua minggu pelaksanaan pelatihan cenderung stabil, sedangkan pada kelompok kontrol yang tidak diberi pelatihan keterampilan regulasi emosi tidak terjadi penurunan bahkan beberapa pada subjek terjadi sedikit peningkatan skor depresi.

Berdasarkan hasil analisis antara baseline dan pretest, diketahui bahwa pada saat pengambilan data awal (baseline) sampai sebelum pelaksanaan pelatihan (pretest) skor depresi pada kelompok eksperimen belum mengalami penurunan.
Berdasarkan uji hipotesis diketahui bahwa hipotesis yang berbunyi ada penurunan depresi yang signifikan pada kelompok eksperimen antara sebelum (pretest) dan sesudah (posttest) diberi perlakuan berupa pelatihan keterampilan regulasi emosi dapat diterima. Penurunan depresi yang signifikan pada kelompok eksperimen ini juga terjadi antara sesudah (posttest) pelatihan dan setelah satu minggu pelaksanaan pelatihan (tindak lanjut 1). Namun demikian, pada saat antara tindak lanjut 1 dan tindak lanjut 2 tidak terdapat penurunan depresi yang signifikan. Hal ini dapat diartikan bahwa skor depresi pada kelompok eksperimen cenderung stabil antara setelah satu minggu pelaksanaan pelatihan (tindak lanjut 1) dan setelah dua minggu pelaksanaan pelatihan keterampilan regulasi emosi (tindak lanjut 2).

Berdasarkan hasil analisis kualitatif, diketahui bahwa hampir seluruh subjek dalam kelompok eksperimen menunjukkan perubahan yang positif berupa peningkatan dalam penguasaan keterampilan regulasi emosi. Beberapa perubahan yang mencolok adalah memahami dan menerima perasaan serta emosi akibat perubahan kondisi fisik yang selama ini diingkari ini menjadi meningkat. Subjek menyadari bahwa emosi tersebut wajar dialami oleh difabel akibat kecelakaan dan tidak lagi mengingkari perasaan dan emosi tersebut.

Selain itu, hampir sebagian besar subjek mampu mengidentifikasi perasaan, emosi, memahami hubungan antara pikiran, perasaan, dan perilaku. Subjek mampu memahami bahwa pikiran dan perasaan yang dimiliki terhadap suatu situasi akan memengaruhi perilakunya terhadap situasi tersebut, sehingga subjek merasa perlu untuk mengubah pikiran negatif menjadi positif agar dapat berpe- 
rilaku yang sebaiknya. Hal ini nampak ketika subjek mengisi worksheet dan studi kasus "situasi yang dihadapi" pada saat mengikuti pelatihan. Subjek juga mampu mengelola emosi dan mengubah emosi negatif menjadi emosi positif dengan memotivasi dan berpikiran positif terhadap suatu situasi. Pada evaluasi hasil dan wawancara, subjek mengungkapkan bahwa ketika merasa sedih maupun putus asa, subjek mencoba mengingat orang tua dan keluarganya di rumah sehingga subjek dapat kembali bersemangat. Oleh karena itu, subjek telah menemukan solusi dalam menghadapi pengalaman emosi dan perubahan kondisi fisik yaitu dengan berpikir positif serta menerapkan keterampilan tersebut dalam kehidupan seharihari.

Ketika subjek melakukan relaksasi pernafasan diafragma, subjek merasakan perubahan, yaitu subjek merasa nyaman, rileks, dan tenang. Selama ini subjek mengalami ketegangan fisik ketika mengalami emosi negatif seperti marah, menyesal, dan bersalah. Setelah memperoleh keterampilan relaksasi pernafasan diafragma, subjek dapat mengelola ketegangan fisik yang dirasakan dan merasa lebih tenang.

Subjek dalam kelompok eksperimen telah mampu mengekspresikan emosi yang dimilikinya setelah mengikuti pelatihan. Hal ini nampak ketika subjek berlatih untuk mengungkapkan perasaan dengan menulis surat ungkapan perasaan kepada seseorang. Meskipun pada awalnya sulit, akan tetapi sebagian besar subjek telah mampu menuliskan ungkapan permintaan maaf maupun terima kasih atas dukungan dari orang-orang terdekatnya.

Hasil penelitian efektivitas pelatihan keterampilan regulasi emosi terhadap penurunan depresi ini sejalan dengan pernyataan Thompson yang dikutip oleh Putnam (2005), bahwa individu yang mempunyai regulasi emosi tinggi dapat mengetahui apa yang dirasakan, dipikirkan dan apa yang menjadi latar belakang dalam melakukan suatu tindakan, mampu untuk mengevaluasi emosi-emosi yang dialami sehingga bertindak secara rasional bukan secara emosional, dan mampu untuk memodifikasi emosi yang dialami sehingga dimungkinkan difabel terhindar dari depresi.

Hasil penelitian pengaruh pelatihan keterampilan regulasi emosi terhadap penurunan depresi juga sejalan dengan hasil penelitian yang dilakukan oleh Joorman dan Gotlib (2010) maupun Compare, dkk (2014) yaitu penggunaan strategi regulasi emosi yang adaptif (seperti penilaian kembali) memengaruhi pengurangan emosi stres dan pemulihan depresi, sebaliknya strategi regulasi emosi disfungsional (seperti perenungan dan penekanan emosi) berpengaruh dalam patogenesis depresi dan penyakit fisiologis. Subjek yang telah mampu memahami situasi yang dialami, mengelola dan mengubah emosi negatif dengan emosi positif dengan memotivasi diri menunjukkan bahwa subjek tersebut telah menggunakan strategi regulasi yang adaptif yaitu penilaian kembali, sehingga membantu pemulihan depresi yang dialaminya.

Pelatihan keterampilan regulasi emosi ini dapat dikatakan membantu subjek dalam menangani depresi dengan didasarkan hasil analisis kualitatif dari data wawancara, tugas rumah, worksheet serta lembar evaluasi yang peneliti dapatkan dari subjek. Subjek mengatakan bahwa subjek selalu menerapkan apa yang diperoleh di setiap sesi pelatihan dalam kehidupan sehari-hari. Subjek merasakan manfaat yang besar dari penerapan materi tersebut, misalnya menerapkan relaksasi 
pernafasan diafragma saat menghadapi situasi yang memancing emosi, lebih terbuka dan ekspresif, serta lebih bersabar. Subjek juga dapat mengurangi kelelahan fisik dan sulit tidur yang dialami selama ini dengan mempraktekkan relaksasi pernafasan diafragma dalam kehidupan sehari-hari.

Suasana keakraban sudah dibangun dari awal pelatihan dengan ice breaking perkenalan yang penuh canda tawa. Pada awal pelatihan, beberapa subjek nampak diam dan pasif, akan tetapi lamakelamaan mulai tersenyum dan aktif memberikan pendapat dan masukan kepada fasilitator maupun subjek yang lain. Sikap terbuka juga mulai nampak ketika kegiatan sharing dan menceritakan pengalaman emosi mengenai kejadian traumatis yaitu kecelakaan yang dialaminya. Masing-masing subjek bersedia mengungkapkan perasaannya ketika mengetahui perubahan kondisi fisiknya yang tidak lagi sempurna. Subjek yang lain mendengarkan ungkapan perasaan tersebut, kelompok subjek juga memberikan dukungan dan bantuan kepada subjek lain yang membutuhkan sehingga kelompok subjek saling memotivasi antara satu dengan yang lainnya. Kelompok subjek ini merasa senasib dan sepenanggungan, sehingga semakin banyak perasaan yang diungkapkan maka akan membuat kelompok subjek saling memahami dan mendukung. Kondisi yang demikian juga dapat memberikan dampak positif dalam penyembuhan dan keberhasilan proses pelatihan.

Beberapa subjek yang pada awal pertemuan pelatihan menyembunyikan anggota tubuhnya yang cacat, lama-kelamaan mulai nampak percaya diri, bahkan di akhir sesi pelatihan semua subjek saling menunjukkan luka bakar maupun bekas amputasi yang dimilikinya kepada tim pelatihan. Hal ini menunjukkan bahwa kelompok subjek nampak sudah menerima keadaan dirinya dan bersikap terbuka kepada tim pelatihan.

Partisipasi dari subjek juga mendukung keberhasilan dalam pelatihan. Subjek dalam pelatihan ini kooperatif dan memperhatikan apa yang diberikan fasilitator. Motivasi yang tinggi, sikap terbuka dalam menceritakan pengalaman dalam menghadapi perubahan kondisi fisik, menceritakan pengalaman dan perasaannya selama mengikuti proses pelatihan. Motivasi subjekpun tetap terjaga sampai pelatihan berakhir. Subjek penelitian juga diberikan tugas rumah berupa wawancara difabel berprestasi dan catatan harianku. Melalui tugas rumah wawancara difabel berprestasi, subjek telah mendapatkan pengalaman dalam mengelola emosi dari difabel yang diwawancarai sebagai pembelajaran sehingga subjek dapat menerapkan pengalaman tersebut dalam kehidupan sehari-hari. Sementara melalui tugas rumah catatan harianku, peneliti dan fasilitator dapat memantau sejauhmana subjek mengaplikasikan keterampilan yang dipelajari dari pelatihan pertemuan kedua.

Kendala-kendala yang dialami dalam penelitian ini adalah peneliti kesulitan dalam menentukan jadwal pelatihan yang disesuaikan dengan jadwal subjek dikarenakan padatnya kegiatan yang diadakan oleh BBRSBD Prof. Dr. Soeharso Surakarta bagi subjek yang merupakan siswa baru. Hal ini menyebabkan peneliti menentukan jadwal pelatihan di sore hari dengan berbagai pertimbangan. Pertimbangan tersebut, antara lain: kenyamanan subjek yaitu pelatihan dilaksanakan pada saat waktu luang sehingga tidak mengganggu Kegiatan Belajar Mengajar (KBM) di VAK dan memberikan kesempatan bagi subjek untuk beristirahat setelah KBM di VAK. 
Namun demikian, beberapa subjek masih nampak lelah ketika mengikuti pelatihan setelah melakukan aktivitas KBM seharian.

Kendala lain yang dialami oleh peneliti adalah tempat pelatihan yang kurang kondusif bagi subjek, yaitu subjek mengikuti pelatihan di mushola dengan tidak adanya kursi dan meja yang menyulitkan subjek dalam mengisi worksheet atau mengerjakan tugas yang diberikan fasilitator. Namun demikian, secera keseluruhan subjek nampak kooperatif dan tetap merasa santai dengan keterbatasan tempat dan fasilitas yang ada.

\section{Kesimpulan}

Penelitian ini telah membuktikan bahwa pelatihan keterampilan regulasi emosi efektif dalam menurunkan depresi dari fase pretest hingga fase tindak lanjut 2 (setelah 2 minggu pelaksanaan pelatihan) pada difabel akibat kecelakaan di BBRSBD Prof. Dr. Soeharso Surakarta. Terlihat pula perbedaan yang signifikan antara kelompok yang mendapat perlakuan pelatihan keterampilan regulasi dengan kelompok yang tidak mendapat perlakuan pelatihan keterampilan regulasi emosi.

Keterampilan regulasi emosi yang dimiliki oleh subjek yang telah mengikuti pelatihan keterampilan regulasi emosi menjadi meningkat. Subjek tersebut telah mampu memahami perasaan dan emosi, menerima, mengelola dan mengubah emosi sehingga menjadi lebih sabar dalam menghadapi pengalaman emosi, terutama emosi negatif. Perubahan tersebut membuat subjek mengalami penurunan depresi, antara lain simtom afektif, motivasional, kognitif, fisik dan vegetatif menjadi menurun.
Saran

Difabel akibat kecelakaan diharapkan dapat menerapkan keterampilan regulasi emosi, seperti memahami dan menerima perasaan dan emosi, mengelola dan mengubah emosi negatif menjadi positif untuk mencegah depresi yang dialami dalam menghadapi perubahan kondisi fisik setelah kecelakaan. Bagi pihak BBRSBD Prof. Dr. Soeharso Surakarta dan praktisi difabel diharapkan dapat memberikan program pelatihan keterampilan regulasi emosi sebagai salah satu program rehabilitasi sosial dalam rangka menghadapi pengalaman emosi difabel akibat kecelakaan pada siswa baru angkatan selanjutnya. Peneliti selanjutnya diharapkan dapat mengusahakan ketersediaan fasilitas untuk kenyamanan subjek, seperti meja, kursi dan ruangan yang luas. Penentuan jadwal pelatihan juga penting untuk diperhatikan, seperti melaksanakan pelatihan pada hari libur sehingga pelatihan dapat dimulai pada pagi hari untuk menghindari faktor kelelahan subjek setelah mengikuti kegiatan sehari penuh. Di samping itu, peneliti selanjutnya diharapkan dapat melakukan pendampingan intensif terhadap subjek dan memperhatikan faktor eksternal yang memberikan pengaruh terhadap proses penurunan depresi. Pendampingan intensif ini dilakukan agar mampu mengaplikasikan metode yang diperoleh selama pelatihan dengan tepat. Peneliti selanjutnya juga dapat mengembangkan pelatihan keterampilan regulasi emosi dalam menyelesaikan masalah depresi lebih luas dengan mengadaptasi dan riset pengembangan dari beberapa materi dan metode dari penelitian ini. 


\section{PENURUNAN DEPRESI PADA DIFABEL}

\section{Kepustakaan}

Achmad, S. (1988). Hubungan antara perilaku asertif, stress, dan self-esteem dengan depresi pada mahasiswa baru. Jurnal Psikologi, 16(1), 34-37

Badan Pusat Statistik. (2014). Jumlah kecelakaan, koban mati, luka berat, luka ringan, dan kerugian materi yang diderita tahun 1992-2012. http://www. statisticsindonesia.html. Diakses tanggal 17 November 2014 jam 9:36.

Beck, A.T. (1985). Causes and treatment. Philadelphia: University of Pennsylvania Press.

Candra, P.D. (2014). Laporan praktek kerja profesi psikologi: Kasus individu nonpsikotik di BBRSBD Prof. Dr. Soeharso Surakarta. Surakarta: Magister Psikologi Profesi Universitas Muhammadiyah Surakarta.

Compare, A., Zarbo, C., Shonin, E., Gordon, W.V., \& Marconi, C. (2014). Emotional regulation and depression: a potential mediator between heart and mind. Hindawi Publishing Corporation Cardiovascular Psychiatry and Neurology Volume 2014, doi: 324374.

Greenberg, L.S. (2002). Emotion-focused therapy: Coaching clients to work through theirfeelings. Washington, DC: American Psychological Association.

Gross, J.J. (2006). Handbook of emotion regulation. New York: Guilford Press.

Gross, J.J., \&Thompson, R.A. (2007). Emotion regulation: Conseptual foundations (Chapter 1). Handbook of
Regulation Emotion (pp. 3-24). New York: Guilford Press.

Halgin, R., \& Whitbourne, S.K. (2010). Psikologi abnormal: perspektif klinis pada gangguan psikologis. Jakarta: Salemba Humanika.

Hidayati, N. (2008). Penanganan stres ibuibu korban lumpur panas lapindo dengan pelatihan regulasi emosi. Tesis. Tidak diterbitkan. Yogyakarta: Fakultas Psikologi UGM.

Joorman, J., \& Gotlib, I.H. (2010). Emotion regulation in depression: Relation to cognitive. Inhibition NIH Public Access. 24(2): 281-298. doi:10.1080/ 02699930903407948.

Kemenhub RI. (2011). Perhubungan darat dalam angka 2010. http://www.hubdat. web.id. Diakses tanggal 17 November 2014 jam 9:46.

Putnam, K.M. \& Silk, K.R. (2005). Emotion dysregulation and the development of borderline personality disorder. Jurnal of Development and Psychopatology. 17. 899-925.

Senra, H., Oliveira, R.A., Leaf, I. \&Vieira, C. (2011). Beyond the body image: A Qualitative study on how adults experience lower limb amputation. Clinical Rehabilitation. 26(2) 180-191. doi: $10.1177 / 0269215511410731$

Yusainy, C., Thohary, S., \& Gustomy, R. (2016). \#StopAbleism: Reduksi stigma kepada penyandang disabilitas melalui intervensi bias implisit. Jurnal Psikologi, 43(1), 1 - 15. 